\title{
Social organizations mechanisms for the care of juvenile delinquents to achieve their social protection
}

Altohamy Alpakry Ahmed A bdalkerem (PhD)

Community Organization Department

Faculty of Social Work- Aswan University

Hala A bdel-Azim Madany Ahmed (PhD)

Community Organization Department

Faculty of Social Work- Aswan University 



\section{Social organizations mechanisms for the care of juvenile delinquents to achieve their social protection}

\section{ABSTRACT:}

The study aims to determine the level of Social organizations mechanisms for the care of juvenile delinquents to achieve their social protection, determining the level of the social organizer's role in achieving social protection for juvenile delinquents. This study is categorized as a descriptive one. The two researchers used both types of the social survey method, the comprehensive social survey of the officials working in the juvenile delinquents institutes whose number is (25) persons, comprehensive social survey of the juvenile delinquents whose number is (75) persons. The two researchers conducted a questionnaire to the officials and a questionnaire form to the juvenile delinquents. The study concluded that the general average of the social organizations mechanisms for the care of juvenile delinquents to achieve their social protection as determined by officials is (2.55) which is a high rate. Also, the level of the social organizer's role in achieving social protection for juvenile delinquents as determined by juvenile delinquents is (2.38) and this is a high rate. There are substantial differences that are statistically significant at the moral level of (0.05) between the responses of the officials and those of juvenile delinquents concerning their determination of the level of the social organizer's role in achieving social protection for juvenile delinquents in favour of the officials' responses which make us accept the study hypotheses.

\section{KEYWORDS:}

Mechanisms, Social organizations, care of juvenile delinquents, social protection.

\section{INTRODUCTION:}

The global changes that occurred in the past two decades, and the concepts of human development being on the rise have led to an increase in the attention given to the child recently. "Putting into consideration that their right to a healthy development is a part of humans' rights intellectually and physically" (United Nations Children's Fund, 2005, p. 97)

Statistics show that this group is increasing every year respectively, as the number of juveniles was about 3296 in 2012, 3612 in 2013 and 4673 in 2014 .This indicates that this group is accelerating. The total number of juveniles placed in the Classification and Orientation Center in Cairo which classifies and distributes juveniles all over the 
Republic institutions have reached about 72 juvenile delinquents and 1173 juveniles exposed to delinquency, so the total number in the Classification and Orientation Center was 1245 from 1/1/2016 to 30/6/2016 (the general social defense administration, 2015, p. 3)

The nature of the child's life away from family boundaries, especially during the first stages of his growth and development and the constant and frequent exposure to the hazards of being on the street and the problems related to this without protection, control or guidance, all this makes the child vulnerable to many health, psychological and behavioral threats such as; violence, aggression, introversion and weak relationships with others (Halawa, 2011, p. 17) .This has been confirmed by the study of (Mulins, 2004, p. 363) whose findings proved that the more a child lives away from his/her family, the more vulnerable to deviation he/she is. There are many forms and examples of deviation vulnerability such as; begging and mingling with lowlifes. Statistics have shown that the highest percentage of those vulnerable to deviation is the mixing with lowlifes, with a percentage of $40.8 \%$,then , begging with a percentage of $29.1 \%$.This study also showed that there is an increase in the number of juvenile delinquents inside social organizations (Fahmy, 2000, p. 38). The study of (harries, 1997) which was carried out on one of the juvenile welfare institutions, aims at Juvenile Rehabilitation through developing their life skills. This was showed by the study (shirley, 1998), which aimed at recognizing the possibility of the Rehabilitation of juveniles recovering from deviation through developing their life skills and giving them advice with follow up. One of the most important findings of this study is that social workers and the work team must continue the reform process and the follow up of juveniles after being released to avoid returning back to deviation.

The children placed in social care institutions suffer from family and social deprivation in all its various forms, also community's perception and the negative outlook of the future as the psychological and social needs of the children of social care are not satisfied and do not receive due care from the community (Abaza, 2003, p. 35), in addition to forms of violence and abuse a juvenile is exposed to in social welfare institutions, and this was stated by the study (Leslie, 1998) in its findings which showed that there are a lot of forms of violence a juvenile is exposed to in the social welfare institutions more than those on the street due to the present conditions of the institutions , lack of follow up to juveniles and lack of a suitable 
environment for social harmony which leads to a return back to delinquency .This study also showed the significance of juveniles' vocational training, and the necessity to provide all social protection mechanisms for them. In the light of the above, the phenomenon of juveniles' delinquency is one of the phenomena and the problems which plague societies. This juveniles' delinquency indicates their engagement in the world of crime when they grow up (Al-Ajeeli, 2001 , p. 22) .So, societies gave great attention and extreme care to juveniles' problems and needs .Therefore, Scientists ,researchers, institutions and agencies gave their attention to juveniles' concerns and problems (Ali, 2013, p. 108). This is what was confirmed by the study (cystic \& Lisa, 2000) as it highlighted the necessity to deal with juveniles' problems and to modify their behavior through social organizations to rehabilitate them and transform them into good citizens to integrate into the society through creative programs to protect them. This was shown by (Mafico \& Mushunje, 2010, pp. 261275) who targeted to design creative programs to provide social protection for fragile children. These programs include education, training, social and psychological support through the social organizations. Also, the study of (Badawi, 2009) aimed at determining the obstacles which hinder social organizations. These obstacles are; the weak mechanisms of coordination and support to unify the efforts of the social organizations, the poor officials' awareness of the importance of the process of coordination, cooperation and exchange between the social organizations. This was shown by the study of (Ahmed, 2000), stating that these difficulties are; the weak processes and methods of coordination and cooperation between these social organizations. Thus, the field of juvenile delinquents welfare is one of the most important fields of the professional practice. The social work has proved its effectiveness with this group by its basic methods and help of which is the method of society organization which is considered one of the methods of the professional working with societal institutions (skidmore, 1994, p. 73). The method of society organization aims at strengthening the relations and ties, in addition to the coordination of efforts of the organizations, bodies, groups and individuals to achieve social protection for juvenile delinquents. This study will start from the social pattern theory which means the social organizing which governs the behaviors of the majority of citizens,so they practice all their different aspects of life in a frame (michelm, 1990) .

\section{Ways to benefit from this theory}

We can say that social organizations are considered a whole pattern consisting of a group of sub patterns, the technical team and the different departments....etc. This whole integrates and correlates 
structurally and functionally to achieve the objectives for which it was established. The social organizations as an open social pattern include the following:-(Inputs) which are the strategies and the executive and regulatory regulations which direct the work inside the social organizations, human and material resources inside the organization, employees and officials who provide services for juveniles whether ( educational - social - cultural ......etc.) (Throughputs) which are the professional efforts and measures made so the service goes to the beneficiaries (juvenile delinquents), (outputs) which are the organization achievements and how much they contribute to achieving social protection to their residents,-(Feed back) which is; recognizing the reactions of the beneficiaries of the social organizations services by knowing the juveniles' (the beneficiaries) opinions of this organization so the organization ensures its continuation. The organization benefits from feed-back as follows: *Rephrasing the social organizations aims for the care of juvenile delinquents to achieve their social protection, according to the above, the two researchers found that it is necessary to give due attention to determining the social organizations mechanisms to achieve the social protection for juvenile delinquents .

\section{Identifying the study issue:}

In the light of the above, we find that social organizations lack a lot of the basic mechanisms which reflects negatively on their capabilities of achieving the social protection in the framework of the current changes which place the responsibility on these organizations to have local and national missions, so backing up these organizations mechanisms is one of the trends which must be supported in the practice fields of the social work because social work is an institutional profession done by institutions called in the society organization the term agencies, so the social work profession tries generally and by a particular method of organization to develop these agencies and support their mechanisms to achieve an integration between these agencies and the surrounding environment. In the light of the above studies, the two researchers found that it is necessary to give due attention to determining the level of social organizations mechanisms for the care of juvenile delinquents to achieve their social protection, and based on all this, ,the two researchers elaborated their major research issue as follows: Determining the level of Social organizations mechanisms, and determining the social organizer's role in achieving social protection for juvenile delinquents. 


\section{*Importance of the study:}

1- The spread of the phenomenon of juveniles vulnerable to delinquency, and this has been confirmed by the continuous increase in the number of juvenile delinquents placed in social organizations.

2- The issue of juvenile delinquents is one of the issues which is dangerous to the society and has effects on the society situations whether social, economic or security. Hence, all specialties of the society are required to look for solutions to this issue. The profession of social work is one of these specialties and it has a major role in dealing with social issues.

3- In Egypt, there are 24 penal institutions, including 18 institutions for male children, 6 institutions for girls. The number of cases that benefits from the service of institutions annually is 32,231 cases per year (Hayat Foundation for Development and Community Inclusion, 2011,p.15).

\section{*Aims of the study}

1. Determining the level of Social organizations mechanisms for the care of juvenile delinquents to achieve their social protection.

2. Determining the level of the social organizer's role in achieving social protection for juvenile delinquents.

\section{*Hypotheses of the study}

1. The first hypothesis of the study "It is expected that the level of social organizations mechanisms for the care of juvenile delinquents to achieve their social protection is high.

Testing this hypothesis can be conducted through the following indicators: coordination, cooperation, exchange

2. The second hypothesis of the study: "It is expected that the level of the social organizations' role in achieving social protection for juvenile delinquents is high."

3. The third hypothesis of the study: There are substantial differences that are statistically significant between the responses of the officials and those of juvenile delinquents concerning their determination of the level of the social organizations' role in achieving social protection for juvenile delinquents."

\section{Theoretical framework of the study:}

A-Mechanisms concept: (barker, 1991) identifies it as the knowledge, skills base, methods and theories or the measures used to achieve obvious aims. 


\section{We can identify mechanisms procedural in this study:}

They are the methods used in achieving the social protection for juvenile delinquents represented as follows: coordination, cooperation and exchange.

- Coordination : It is a sequential and continuous process of working together to avoid unnecessary, duplicative and repeated efforts and to avoid conflict because coordination, on the positive side, is the collaboration of people, organizations and the powers to support and consolidate each other and trying, if possible, to increase the effective services which exceed what was done out of necessity (Kiosk, 1996, p. 21). Interest in coordination among organizations created remarkable attention among those engaged in the method of society organization on the basis that the relationships between organizations are the first field of the practice of the method of society organization." Neoseteter "thinks that some scientists considered these relationships the focus of the practice theory in the society organization. (Rothman \& EPration, 1997, p. 1359) Also, coordination helps to find partnership and solidarity opportunities between different organizations and this leads to the union of their resources and the capabilities of all of the network members and the association of the relationships and bonds between them to help achieve the mutual goals (wassermer, 1997, p. 250)

- Cooperation is: defining roles and using methods which lead to non-contradictory decisions, that is, avoiding any contradictory decisions (Abdelaal, 2006, p. 43) .

- Exchange is: an optional activity done between two organizations for achieving subjective, non-subjective or expected goals (Levine \& white , 1970, p. 31), so the method of society organization since its inception confirms the necessity of understanding the factors affecting the achievement of coordination, cooperation and exchange relationships between the social care organizations. As the relationship between the social care organizations was the subject of many studies and theories and in modern societies with interrelationships, it is supposed that there is an urgent need for cooperation between organizations with the aim of coordination with each other (Ross, 1977, p. 66) 


\section{B-Social Organizations concept:}

They are social entities directed towards goals, with the intention of structuring the active systems with identified limits (Craftion, 2004, p. 74) . Some believe that Social Organizations consist of four major components ,which are: (zastrow \& ashmany, 2004, p. 33)

1- Social entities or units consisting of a group of people.

2- Having specified goals for which they were established.

3- There is mutual dependence between their components and their activities.

4- They are linked to the external environment "that is, working in the light of the general goals in society"

\section{We can identify Social Organizations procedural in this study:}

- They are non-governmental and governmental organizations aiming at achieving the social protection for juvenile delinquents .They were established according to advance planning, based on well-studied, scientific foundation.

- The aim of establishing them is achieving specified goals for juvenile delinquents (accommodation, social, health, psychological, rehabilitation), with the advantage of having direct contact with juvenile delinquents.

\section{C- Care of juvenile delinquents concept:}

They are the organized efforts, services and programs ,governmental ,non-governmental and international which help those who were unable to satisfy their basic needs for development and positive interaction with their community in the frame of the existing social systems to achieve the utmost adaptation to the social environment (Othman, 1980, p. 113). We mean by juvenile delinquents that they are the group placed in the care institutions and they come from homeless places and it is dangerous for them to go back to street life (world health organization, 1993, p. 41)

We can identify juvenile delinquent procedurally in this study:

- A juvenile aged between (12:15) years, and when the juvenile is in a situation exposing him/her to the danger of delinquency.

- Going to the institution on his own or one of his relatives. There is no judgment against him/her, and no felony committed.

D -Social protection concept: It is the group of social programs which basically aims at improving and promoting the human being on all sides, social, economic and psychological (Koueider, 2000, p. 13) . 
Social protection consists of the policies and the programs aiming at reducing poverty and weakness through enhancing labor market efficiency, which reduces people exposure to dangers and enhances their ability to manage the economic and social risks, such as, unemployment, exclusion, illness, disability and old age. (United Nations Research institute for Social Development, 2010) .Social protection helps to enhance empowerment and more security through increasing awareness of danger management, in addition to facilitating the investments returning from the poor, thus, supporting the development of the human capital, through expanding the abilities of the poor persons and the weak groups, which help ending and stopping poverty passing through generations (Promoting pro-poor growth , 2009, pp. 17-19)

Social protection mechanisms inside social organizations are as the following:

- Traditional official social protection mechanisms: Such as: education, training, health, price control and support.

- Unofficial protection mechanisms: Such as: the management and diversification of family activity, charitable aids and creating cooperation, coordination and exchange between the social organizations (El-Sayed, 2002, p. 745)

- Conducting surveys and studies of the marginalized groups, preparing social protection programs, establishing strategic projects to achieve the social protection(AbuQura, 2010, p. 58)

\section{We can identify social protection procedural in this study:}

- A group of activities, services and businesses carried out by the social care institutions which contribute to satisfying juvenile delinquents needs.

- It reduces the dangers juvenile delinquents are exposed to.

\section{Methodology:}

1- Study type: Analytical descriptive.

2- Method of study: the comprehensive social survey of the juvenile delinquent "beneficiaries of the social organizations whose number is (75) persons, the comprehensive social survey of the social workers in the juvenile delinquents institutions whose number is (25) persons. 


\section{3- Study tools:}

A- A questionnaire to the officials concerning social organizations mechanisms for the care of juvenile delinquents to achieve their social protection:

The two researchers conducted a questionnaire to the officials. Face validity was done to the tool after presentation to (5) of the members of the staff of the Faculty of social work University of Helwan, Faculty of social work University of Aswan, depending on a minimum of agreement rate not less than (80\%), deleting some phrases and rephrasing some. According to this the form has been finally phrased. A reliability statistic has been done to a sample of (10) persons of the officials using Cronbach Alpha coefficient and reliability coefficient is (0.86), and it is an appropriate level of reliability statistic.

B- A questionnaire to the juvenile delinquents concerning the social organizer's role in achieving social protection for juvenile delinquents:

Building the tool in its initial form depending on the theoretical framework of the study and the previous studies linked to the study subject. Face validity was done to the tool after presentation to (5) of the members of the staff of the Faculty of social work University of Helwan, Faculty of social work University of Aswan, depending on a minimum of agreement rate not less than $(80 \%)$, deleting some phrases and rephrasing some. According to this the form has been finally phrased. A reliability statistic has been done to a sample of (10) persons of the juvenile delinquents using Cronbach Alpha coefficient and reliability coefficient is $(0.91)$, and it is an appropriate level of reliability statistic.

\section{4-Statistical analysis methods:}

The data has been processed through a computer using program (SPSS. V. 17.0) statistical packages for the social sciences, statistical methods were applied as follows:

A- Duplicates and percentages. B- Arithmetic average: to judge the level of Social organizations mechanisms for the care of juvenile delinquents to achieve their social protection, where the beginning and end of the 3 point scale categories: Yes (three marks), to some degree (two marks), no (one mark). Coded data were entered into the computer and to determine the length of 3 point scale cells (minimum and maximum limits), they calculated the range $=$ maximum value- 
minimum value $(3-1=2)$, is divided on the scale cells to get the length cell debugger $(2 / 3=0.67)$ and then add this value to the minimum value in the scale or the beginning of the scale which is 1 to determine the maximum limit of this cell.

Thus the length of cells became as follows :

Table (1) shows the arithmetical levels

\begin{tabular}{|l|l|}
\hline Low level & $\begin{array}{l}\text { If the average value for a phrase or dimension ranges from 1 to } \\
\text { less than } 1.67\end{array}$ \\
\hline Average level & $\begin{array}{l}\text { If the average value for a phrase or dimension ranges from 1.67 } \\
\text { to less than 2.35 }\end{array}$ \\
\hline High level & $\begin{array}{l}\text { If the average value for a phrase or dimension ranged from 2.35 } \\
\text { to less than 3 }\end{array}$ \\
\hline
\end{tabular}

C-Standard deviation: It is to identify the extent of dispersion or non dispersion of the interviewee's responses; it also helps to order the phrases with the arithmetic average.

D-Range: It is calculated by the difference between the highest value and the lowest value.

E- Cronbach Alpha reliability coefficient: for reliability values estimates of the study tools.

F- Independent - Samples T-Test: To realize the differences and their statistical indications, in the variations divided into two groups only. (Testing hypotheses of the study).

\section{5- Study Areas:}

A-Spatial domain: In this study it is specified in educational facilities in Giza, Classification and Orientation Center in Giza, Reasons for choosing the spatial domain: These institutions offer care of juveniles vulnerable to delinquency (study category).

- These institutions are considered some of the biggest juvenile delinquents welfare institutions, which abled the two researchers do the study.

- Availability of the study samples in the institutions mentioned above, the institutions agreement to apply the study, social workers agreement to cooperate with the two researchers.

B-The human area: - The social workers in the juvenile delinquents institutions whose number is (25) persons.

- The juvenile delinquents whose number is (75) persons. They were chosen according to the following: Juvenile aged between (12:15) years, the juvenile who is able to answer the researchers' questions. 


\section{Egyptian Journal of Social Work (EJSW) \\ http://ejsw.journals.ekb.eg \\ Print ISSN: 2356-9204 Online ISSN: 2356-9212 Vol 10, Issue 1, June 2020}

- The juvenile against whom there is no judgment, and no felony committed, and when the juvenile is in a situation exposing him/her to the risk of delinquency.

C- Study time area: Period of collecting field data was from $1 / 8 / 2018$ to $3 / 10 / 2018$.

\section{- $\quad$ Results of field study:}

Table (2) shows coordination as a mechanism of achieving the social protection for juvenile delinquents care as determined by the officials.

\begin{tabular}{|c|c|c|c|c|}
\hline $\mathrm{No}$ & Phrases & $\begin{array}{l}\text { arithmetic } \\
\text { average }\end{array}$ & $\Sigma$ & order \\
\hline 1 & $\begin{array}{l}\text { There is continuous coordination between the } \\
\text { organization and some social organizations to } \\
\text { achieve social protection for juvenile delinquents. }\end{array}$ & 2.76 & 0.6 & 1 \\
\hline 2 & $\begin{array}{l}\text { There is coordination between the organization and } \\
\text { some social organizations for making an integrated } \\
\text { plan to achieve social protection for juvenile } \\
\text { delinquents. }\end{array}$ & 2.28 & 0.54 & 5 \\
\hline 3 & $\begin{array}{l}\text { There is coordination between the organization and } \\
\text { some social organizations for carrying out mutual } \\
\text { projects to achieve social protection for juvenile } \\
\text { delinquents. }\end{array}$ & 2.32 & 0.75 & 4 \\
\hline 4 & $\begin{array}{l}\text { There is coordination between the organization and } \\
\text { some social organizations for preventing } \\
\text { duplication of services provided for juvenile } \\
\text { delinquents to achieve social protection for them. }\end{array}$ & 2.72 & 0.46 & 2 \\
\hline 5 & $\begin{array}{l}\text { Devising a public policy between the organization } \\
\text { and some social organizations by which plans and } \\
\text { programs are carried out through shared action to } \\
\text { achieve social protection for them.. }\end{array}$ & 2.52 & 0.59 & 3 \\
\hline & Total Variant & 2.52 & 0.31 & $\begin{array}{l}\text { High } \\
\text { level }\end{array}$ \\
\hline
\end{tabular}

The previous table shows that: the level of coordination as determined by the officials is high with an average of (2.52), according to the order of arithmetic Average: first came :There is continuous coordination between the organization and some social organizations to achieve social protection for juvenile delinquents with the average of (2.76),second came : There is a coordination between the organization and some social organizations for preventing duplication of services provided for juvenile delinquents to guarantee social protection for them .with arithmetic average(2.72), finally came: There is coordination between the organization and some social 
organizations for making an integrated plan to achieve social protection for juvenile delinquents with arithmetic average (2.28).

Table (3) shows cooperation as a mechanism of achieving the social protection for juvenile delinquents care as determined by the officials.

$(\mathrm{N}=25)$.

\begin{tabular}{|c|c|c|c|c|}
\hline No & phrases & $\begin{array}{l}\text { arithmetic } \\
\text { average }\end{array}$ & $\Sigma$ & order \\
\hline 1 & $\begin{array}{l}\text { The organization and some social organizations } \\
\text { cooperate to determine juvenile delinquents } \\
\text { needs to achieve social protection for them. }\end{array}$ & 2.16 & 0.62 & 5 \\
\hline 2 & $\begin{array}{l}\text { The organization and some social organizations } \\
\text { cooperate to face juvenile delinquents } \\
\text { complications to achieve social protection for } \\
\text { them. }\end{array}$ & 2.24 & 0.44 & 4 \\
\hline 3 & $\begin{array}{l}\text { The organization signs cooperation protocols } \\
\text { with other organizations to carry out joint plans } \\
\text { to face juvenile delinquents problems to achieve } \\
\text { social protection for them. }\end{array}$ & 2.36 & 0.49 & 3 \\
\hline 4 & $\begin{array}{l}\text { The organization and some social organizations } \\
\text { organize training courses for the employees on } \\
\text { how to achieve social protection for the juvenile. }\end{array}$ & 2.72 & 0.54 & 1 \\
\hline 5 & $\begin{array}{l}\text { The organization and some social organizations } \\
\text { cooperate to benefit from their experiences in } \\
\text { achieving social protection for the juvenile. }\end{array}$ & 2.52 & 0.51 & 2 \\
\hline & Total Variant & 2.4 & 0.19 & $\begin{array}{l}\text { High } \\
\text { level }\end{array}$ \\
\hline
\end{tabular}

The previous table shows that: the level of cooperation as determined by the officials is high with arithmetic Average (2.4), according to the order of arithmetic Average: first came ;the organization and some social organizations organize training courses for the employees on how to achieve social protection for the juvenile with arithmetic average (2.72), second came; the organization and some social organizations cooperate to benefit from their experiences in achieving social protection for the juvenile with arithmetic average (2.52),fi nally came; the organization and some social organizations cooperate to determine juvenile delinquents needs to achieve social protection for them with arithmetic average (2.16) 
Table (4) shows exchange as a mechanism of achieving the social protection for juvenile delinquents care as determined by the officials.

$(\mathrm{N}=25)$

\begin{tabular}{|l|l|c|c|c|}
\hline No & \multicolumn{1}{|c|}{$\begin{array}{c}\text { Phrases } \\
\text { arithmetic } \\
\text { average }\end{array}$} & $\mathbf{\Sigma}$ & order \\
\hline $\mathbf{1}$ & $\begin{array}{l}\text { The organization exchanges some policies with } \\
\text { some social organizations to determine juvenile } \\
\text { delinquents needs to achieve social protection for } \\
\text { them. }\end{array}$ & 2.28 & 0.54 & 4 \\
\hline $\mathbf{2}$ & $\begin{array}{l}\text { The organization and some social organizations } \\
\text { exchange training courses for the employees of the } \\
\text { organization and the social organizations to achieve } \\
\text { social protection for them . }\end{array}$ & 2.16 & 0.55 & 5 \\
\hline $\mathbf{3}$ & $\begin{array}{l}\text { The organization and some social organizations } \\
\text { exchange views about social protection for juvenile } \\
\text { delinquents. }\end{array}$ & 2.4 & 0.71 & 3 \\
\hline $\mathbf{4}$ & $\begin{array}{l}\text { The organization and some social organizations } \\
\text { exchange data base they have on juvenile } \\
\text { delinquents to achieve social protection for them }\end{array}$ & 2.56 & 0.51 & 1 \\
\hline $\mathbf{5}$ & $\begin{array}{l}\text { The organization and some social organizations } \\
\text { exchange the experiences they have for dealing } \\
\text { with juvenile delinquents to achieve social } \\
\text { protection for them }\end{array}$ & 2.52 & 0.51 & $\mathbf{0 . 2 4}$ \\
\hline & $\begin{array}{l}\text { High } \\
\text { level }\end{array}$ \\
\hline
\end{tabular}

The previous table shows that: the level of exchange as determined by the officials is high with arithmetic Average (2.38), according to the order of arithmetic Average: First came; the organization and some social organizations exchange data base they have on juvenile delinquents to achieve social protection for them with arithmetic Average (2.56),second came; the organization and some social organizations exchange the experiences they have for dealing with juvenile delinquents to achieve social protection for them with arithmetic Average (2.52), finally came; the organization and some social organizations exchange training courses for the employees of the organization and the social organizations to achieve social protection for them with arithmetic Average (2.16) We conclude from the above that the general average of the social organizations mechanisms for the care of juvenile delinquents to achieve their social protection as determined by the officials is( 2.43), and this is a high rate which fulfills the first aim of the study. 
Table (5) shows clarifies the role of the social organization in achieving the social protection for juvenile delinquents care as determined by the officials.

$(\mathrm{N}=25)$

\begin{tabular}{|c|l|c|c|c|}
\hline No & \multicolumn{1}{|c|}{ Phrases } & $\begin{array}{c}\text { arithmetic } \\
\text { average }\end{array}$ & $\mathbf{\Sigma}$ & order \\
\hline $\mathbf{1}$ & $\begin{array}{l}\text { Try to resolve the disputes that exist between the } \\
\text { juvenile and the family to achieve social protection } \\
\text { for them. }\end{array}$ & 2.68 & 0.48 & 1 \\
\hline $\mathbf{2}$ & $\begin{array}{l}\text { Develop the juvenile's ability to take the social } \\
\text { responsibility to achieve social protection for them. }\end{array}$ & 2.56 & 0.51 & 3 \\
\hline $\mathbf{3}$ & $\begin{array}{l}\text { Cooperate with the organization's work team to } \\
\text { achieve the juvenile's aftercare to achieve social } \\
\text { protection for them. }\end{array}$ & 2.32 & 0.48 & 5 \\
\hline $\mathbf{4}$ & $\begin{array}{l}\text { Observe the juvenile's behavior in the community to } \\
\text { follow up the measures taken with him/her to achieve } \\
\text { social protection for them. }\end{array}$ & 2.56 & 0.58 & 4 \\
\hline $\mathbf{5}$ & $\begin{array}{l}\text { Stop the juvenile from engaging in any action that } \\
\text { may lead him/her to delinquency to achieve social } \\
\text { protection for them }\end{array}$ & 2.64 & 0.57 & 2 \\
\hline & \multicolumn{2}{|c|}{ Total Variant } & $\mathbf{0 . 2 5}$ & $\begin{array}{l}\text { High } \\
\text { level }\end{array}$ \\
\hline
\end{tabular}

Table (6) shows clarifies the role of the social organizer in achieving social protection for delinquent juveniles as well as delinquent juveniles.

\begin{tabular}{|c|l|c|c|c|}
\hline No & \multicolumn{1}{|c|}{ Phrases } & \multicolumn{1}{|c|}{$\begin{array}{c}\text { arithmetic } \\
\text { average }\end{array}$} & $\Sigma$ & order \\
\hline $\mathbf{1}$ & $\begin{array}{l}\text { The social organizer seeks to resolve the } \\
\text { differences that arise between you and your family } \\
\text { to achieve social protection for you. }\end{array}$ & 2.72 & 0.45 & 1 \\
\hline $\mathbf{2}$ & $\begin{array}{l}\text { The social organizer develops your ability to take } \\
\text { social responsibility to achieve social protection for } \\
\text { you. }\end{array}$ & 2.17 & 0.6 & 4 \\
\hline $\mathbf{3}$ & $\begin{array}{l}\text { The social organizer cooperates with the } \\
\text { organization's team to achieve social protection for } \\
\text { you. }\end{array}$ & 2.39 & 0.68 & 3 \\
\hline $\mathbf{4}$ & $\begin{array}{l}\text { The social organizer observes your behavior in the } \\
\text { social environment to provde social protection for } \\
\text { you }\end{array}$ & 2.17 & 0.62 & 5 \\
\hline $\mathbf{5}$ & $\begin{array}{l}\text { The social organizer prevents you from performing } \\
\text { any work that might expose you to delinquency to } \\
\text { achieve social protection for you. }\end{array}$ & 2.45 & 0.62 & 2 \\
\hline & Total Variant & $\mathbf{2 . 3 8}$ & $\mathbf{0 . 3 5}$ & $\begin{array}{c}\text { High } \\
\text { level }\end{array}$ \\
\hline
\end{tabular}


The previous two tables shows that: the level of the social organizer's role in achieving social protection for juvenile delinquents is high as determined by the juvenile delinquents with arithmetic average (2.38), and as determined by the officials is also high ,with arithmetic average( 2.55), and this is according to the order of arithmetic Average: The juvenile delinquents and the officials shared the first order which is; I try to resolve the disputes that exist between the juvenile and the family with arithmetic average (2.68), and the juvenile delinquents and the officials shared the second order which is; I stop the juvenile from engaging in any action that may lead him/her to delinquency to achieve social protection for them with arithmetic average( 2.64 ), finally came ;I cooperate with the organization's work team to achieve the juvenile's aftercare with arithmetic average (2.32). We conclude from the above that the general average of the social organizer's role in achieving social protection for juvenile delinquents as determined by the officials and the juvenile delinquents is high, which achieves the second aim of the study.

\section{The third theme: Testing hypotheses of the study:}

Table (7) shows the level of Social organizations mechanisms for the care of juvenile delinquents to achieve their social protection $(\mathrm{N}=\mathbf{2 5})$

\begin{tabular}{|c|c|c|c|c|c|}
\hline No & mechanisms & $\begin{array}{c}- \\
\text { arithmetic } \\
\text { average }\end{array}$ & $\boldsymbol{\Sigma}$ & level & order \\
\hline $\mathbf{1}$ & Coordination & 2.52 & 0.31 & high & 1 \\
\hline $\mathbf{2}$ & Cooperation & 2.4 & 0.19 & high & 2 \\
\hline $\mathbf{3}$ & Exchange & 2.38 & 0.24 & high & 3 \\
\hline \multicolumn{2}{|c|}{ Total mechanisms } & $\mathbf{2 . 4 3}$ & $\mathbf{0 . 1 8}$ & \multicolumn{2}{|c|}{ High level } \\
\hline
\end{tabular}

The previous table shows that: Social organizations mechanisms for the care of juvenile delinquents to achieve their social protection as determined by the officials are as follows:

- The first is coordination with arithmetic average (2.52), the second is cooperation with arithmetic average (2.4), the third is exchange with arithmetic average (2.38),

- $\quad$ Studying this table, we find that its results indicate the general average of the social organizations mechanisms for the care of juvenile delinquents to achieve their social protection as determined by the officials is ( 2.43), and this is a high rate which makes us accept the first hypothesis of the study, which is; "It is expected that the level of social organizations 
mechanisms for the care of juvenile delinquents to achieve their social protection is high."

Table (8) shows the level of the social organizer's role in achieving social protection for juvenile delinquents.

\begin{tabular}{|c|c|c|c|c|c|c|}
\hline No & Dimensions & $\begin{array}{c}\text { Research } \\
\text { community }\end{array}$ & $\mathbf{N}$ & $\begin{array}{c}\text { Arithmetic } \\
\text { average }\end{array}$ & $\begin{array}{c}\text { Standard } \\
\text { deviation }\end{array}$ & level \\
\hline $\mathbf{1}$ & \begin{tabular}{c} 
the social \\
organizer's role \\
in achieving \\
\cline { 3 - 7 } \\
social \\
protection \\
for juvenile \\
delinquents.
\end{tabular} & The officials & 25 & 2.55 & 0.25 & high \\
\cline { 2 - 7 } & $\begin{array}{c}\text { the juvenile } \\
\text { delinquents }\end{array}$ & 75 & 2.38 & 0.35 & high \\
\hline
\end{tabular}

The previous table shows that: the level of the social organizer's role in achieving social protection for juvenile delinquents as determined by the officials is( 2.55), and this is a high rate, also the level of the social organizer's role in achieving social protection for juvenile delinquents as determined by the juvenile delinquents is (2.38), and this is a high rate. This makes us accept the second hypothesis of the study, which is; "It is expected that the level of the social organizer's role in achieving social protection for juvenile delinquents is high."

Table (9) shows the moral differences between the responses of the officials and those of juvenile delinquents concerning their determination of the level of the social organizer's role in achieving social protection for juvenile delinquents using T-Test $(\mathrm{N}=\mathbf{1 0 0})$

\begin{tabular}{|c|c|c|c|c|c|c|c|c|}
\hline No & Dimensions & $\begin{array}{c}\text { Research } \\
\text { community }\end{array}$ & $\begin{array}{c}\text { number } \\
\mathbf{N}\end{array}$ & $\begin{array}{c}\text { Arithmetic } \\
\text { average }\end{array}$ & $\begin{array}{l}\text { Standard } \\
\text { deviation }\end{array}$ & $\begin{array}{l}\text { Degree of } \\
\text { freedom } \\
\text { (df) }\end{array}$ & $\begin{array}{c}\mathrm{T} \\
\text { value }\end{array}$ & indication \\
\hline \multirow[b]{2}{*}{1} & \multirow{2}{*}{$\begin{array}{l}\text { Total of the } \\
\text { social } \\
\text { organizer's } \\
\text { role }\end{array}$} & The officials & 25 & 2.55 & 0.25 & \multirow[b]{2}{*}{98} & \multirow[b]{2}{*}{2.247} & \multirow[b]{2}{*}{$*$} \\
\hline & & Juveniles & 75 & 2.38 & 0.35 & & & \\
\hline
\end{tabular}

** Moral at (0.01)

* moral at $(\mathbf{0 . 0 5})$

- The previous table shows that: There are substantial differences that are statistically significant at the moral level of $(0.05)$ between the responses of the officials and those of juvenile delinquents concerning their determination of the level of the social organizer's role in achieving social protection for juvenile delinquents in favour of the officials' responses. This makes us accept the third hypothesis of the study, which is; "There are substantial differences that are statistically significant between the responses of the officials and those of juvenile delinquents concerning their determination of the level of the social 
organizer's role in achieving social protection for juvenile delinquents .

- Substantial differences were found between the responses were of officials and juvenile delinquents in order to determine the actual level of performance of the role of the social organizer from the point of view of juvenile delinquents on the one hand and from the point of view of social workers on the other, so as to avoid the bias of the role of the social organizer from the point of view of social workers.

\section{Discussion of the results:}

- Results linked to achieving the first aim of the study, which is: Determining the level of social organizations mechanisms to achieve social protection for the care of juvenile delinquents: The level of coordination as determined by the officials is high with arithmetic Average (2.52), according to the order of arithmetic Average: first came :There is continuous coordination between the organization and some social organizations to achieve social protection for juvenile delinquents with arithmetic average (2.76),second came :There is coordination between the organization and some social organizations for preventing duplication of services provided for juvenile delinquents with arithmetic average(2.72). This was shown in the study of " Azza Mohamed Hassanein (2009), the increase of the organization officials' awareness of the importance of coordination between the social care organizations.

- The level of cooperation as determined by the officials is high with arithmetic Average (2.4), according to the order of arithmetic Average: first came ; the organization and some social organizations organize training courses for the employees on how to achieve social protection for the juvenile with arithmetic average (2.72),second came; the organization and some social organizations cooperate to benefit from their experiences in achieving social protection for the juvenile with arithmetic average (2.52),finally came; the organization and some social organizations cooperate to determine juvenile delinquents needs with arithmetic average (2.16).So, we recommend that the work team and the officials determine juvenile delinquents needs in order of priority. This was confirmed by the study "Mokstas and Wallace Lwiza M,W.LISA (2000)" as it highlighted the 
necessity to satisfy juveniles needs, solve their problems and modify their behavior.

- The level of exchange as determined by the officials is high with arithmetic Average (2.38), according to the order of arithmetic Average: first came ;the organization and some social organizations exchange data base they have on juvenile delinquents with arithmetic average (2.56). This was confirmed by Marry Ross 1977" who highlighted in the book " community organization", the importance of coordination ,cooperation and exchange between the social organizations for preventing duplication and conflict when providing services for the beneficiaries .Second came; the organization and some social organizations exchange the experiences they have for dealing with juvenile delinquents with arithmetic Average (2.52),finally came; the organization and some social organizations exchange training courses for the employees of the organization and the social organizations with arithmetic Average (2.16).So, we recommend that the officials realize the importance of exchanging and holding training courses for the employees of the organization .

- Results linked to achieving the second aim of the study, which is: determining the level of the social organizer's role in achieving social protection for juvenile delinquents as determined by the officials is( 2.55), and this is a high level, according to the order of arithmetic Average: First came; try to resolve the disputes that exist between the juvenile and the family with arithmetic average (2.68), second came ;I stop the juvenile from engaging in any action that may lead him/her to delinquency with arithmetic average( 2.64), finally came ;I cooperate with the organization's work team to achieve the juvenile's aftercare with arithmetic average (2.32).This conforms to the study of Wilson- Shirley" 1996 " which showed the importance of the social organizer's role and the work team in giving advice and follow up for the juveniles to ensure that they do not switch back to delinquency.

- Also, the level of the social organizer's role in achieving social protection for juvenile delinquents as determined by the juvenile delinquents is high with arithmetic Average( 2.38), according to the order of arithmetic Average: First came; the social organizer tries to resolve the disputes that exist between 
my family and I with arithmetic average (2.72), second came ; ;the social organizer stops me from engaging in any action that may lead me to delinquency with arithmetic average( 2.45),finally came ;the social organizer helps me join the vocational training according to my abilities with arithmetic average (2.17). This was shown in the study "Acoca- Leslie 1998" which highlighted the importance of the vocational training for the juvenile according to his/her abilities.

\section{Recommendations of the study:}

It is necessary for the method of society organization to engage in the field of the care of juvenile delinquents, using its philosophy, tools and strategies to contribute to achieving their social protection through the following:

- It is necessary to reconsider the process of vocational preparation of the social organizer who deals with the juvenile delinquents.

- We recommend the necessity of giving due attention to the social organizations mechanisms which help to achieve social safety for juvenile delinquents.

- We recommend the necessity of reaching decisions, receiving general agreement, which contribute to supporting social protection for juvenile delinquents.

- We recommend the necessity of holding continuous discussions between the social organizations to get to know the mechanisms which achieve social protection for juvenile delinquents.

\section{REFRENCES}

Abaza, A. A.-S. (2003). Children and Adolescents at Risk. Cairo: The AngloEgyptian Library.

Abdelaal, A. H. (2006). community organization theory and practice. Cairo: Dar AlMohandes for Printing and Publishing.

AbuQura, K. A.-A. (2010). Towards reforming social protection systems in Egypt. Cairo: National Planning Institute.

Ahmed, T. M. (2000). The relationship between social organizations and achieving goals . Tomadder Mustafa Ahmed: The relationship between social organiJournal of Social work Studies and Humanities, 9.

Al-Ajeeli, Y. S. (2001). The Social Reality of Delinquent Juveniles. Oman: Damiri Publishing Office.

Ali, M. A.-M. (2013). Introduction to Social Work. Cairo: The Arab Renaissance Library.

Badawi, A. M. (2009). Effective efforts of civil society organizations in achieving integrated care to protect the rights of children at risk, research published . journal of studies in social work and humanities. Faculty of Social work. Helwan University. 
Barker, r. (1991). Social work dictionary (2 ed.). washington: N.A.S.W press.

Craftion, j. (2004). generalist practice with organization and communions. new york: plgrave.

Cystic, M., \& Lisa, W. (2000). Attitudes of Louisiana practitioners toward rehabilitation of juvenile offenders. journal of criminal justice monroe.

El-Sayed, O. A. (2002). Social Protection in Egypt Towards an Integrated Social Policy. Scientific Journal of Economics and Trade, D.T., p. 745.

Fahmy, M. S. (2000). Street Children Civilization Tragedy in the Third Millennium. Alexandria: Modern University Office.

Halawa, M. E.-S. (2011). Childhood Legislation and Organizations. Alexandria: University Knowledge House.

Harries, L. (1997). impact and outcome evaluation of positive directions , a Dallas based prevention and intervention program to reduce juvenile delinquency and substance abuse . 1. Linda harries :impact and outcome evaluation of positive directions , a Dallas based preventioTexas: university of north texas.

Kiosk, M. B. (1996). Community Organization from aid to defense. Alexandria: Muhammad Bahjat Jadallah Kiosk: Organizing sociScientific office for Computers, Publishing and Distribution.

Koueider, I. (2000). What is social and conceptual protection? A holistic vision. Cairo: Renaissance Library.

Leslie, A. (1998). the violation of American girl at home on the street and in the juvenile justice system. Journal of crime and delinquency, 7.

Levine, S., \& white, p. (1970). Exchange as a conceptual frame work for the study of inter organizational relationship. new york: council on social work education .

Mafico, M., \& Mushunje, M. (2010). Social protection for orphans and vulnerable children in Zimbabwe . journal of international social work, 53(2).

Michelm, a. (1990). the mackmillan student encyclopedia of sociology. london: mackmillan .

Mulins, A. (2004). the relationship between juvenile delinquency and family unit structure . west virginia: marshal university.

Othman, A.-F. (1980). Introduction to Social Work. Cairo: The Anglo-Egyptian Library.

Promoting pro-poor growth . (2009). policy guidance note: social protection. new york: OECD press.

Ross, M. (1977). community organization . new York : harper press.

Rothman, J., \& EPration, 1. (1997). social planning and community of social work. new york: N.A.S.W.

Shirley, W. (1998). the effect of pre-release transition services on the recidivism of habituated recapitulated juvenile delinquents . new york,U.S.A.: the international university.

Skidmore, R. (1994). introduction to social Work (6 ed.). england: international inc.

The general social defense administration. (2015). Statistics . Giza.Egypt: Statistics and classification center.

United Nations Children's Fund. (2005). the state of the world children 2000 excluded and invisible. new york: unicef press. 


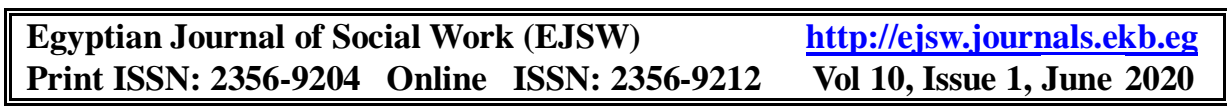

United Nations Research institute for Social Development. (2010). combating poverty and inequality: structural change. journal of social policy and politics.

Wassermer, S. (1997). social network analysis methed sond apil contains . new york: palgrave.

World health organization. (1993). aprogram on substance abuse on way street report on palse of the street children practice . geneva.

Zastrow, C., \& ashmany, K. (2004). Charles zastrow, ashmany-Karen k. kerst, Understanding human behavior and social environment, united states: Thomson books cole, 2004, P33. united states: Thomson books cole.

Hayat Foundation for Development and Community Inclusion(2011) . Juveniles and their care homes, field study, research and studies program. 
